\title{
EDITORIAL
}

\section{Trump travel ban means academics must strengthen, not sever, US ties}

\author{
Matthew B. Stanbrook MD PhD \\ Cite as: CMAJ 2017 March 20;189:E420-1. doi: 10.1503/cmaj.170247
}

A week after taking office, US President Donald Trump issued an executive order suspending entry into the United States of nationals from seven predominantly Muslim countries. A week later, that executive order was itself suspended by a US court. Despite this and other twists and turns since, including a new, slightly narrower executive order, the damage was done: visas have been cancelled, and widespread confusion has reigned about who may be denied entry. This is made worse by reports that some US border officials are exercising their considerable latitude and authority by detaining or excluding Muslims from countries not even covered by the ban and, in some cases, those who are US citizens.

The executive order immediately produced national and international outrage - not least among academics. Thousands of US academics have signed letters and petitions denouncing the ban. ${ }^{1}$ But many international physicians, scientists and other academics have gone further, pledging to boycott conferences held in the US in solidarity with Muslim colleagues who might be prohibited from joining them. ${ }^{2}$ Some are even refusing to perform peer reviews for US journals, arguing that such journals will pay taxes to the government responsible for the ban. ${ }^{3}$

In the face of a political action widely condemned as unjust and unconstitutional, and seemingly fuelled by racism and Islamophobia, a moral stand is necessary and entirely justified. But the shape that such a stand ought to take, its effectiveness and its possible unintended consequences bear careful scrutiny.

US professional societies and academic institutions - including the journals they publish - are the wrong target for protest, especially as hundreds of them, including leading medical organizations, have condemned the executive order. Political solutions will never arise from scientists and scholars - on whom the world depends critically for solutions to its urgent problems - breaking ties with one another. Science, especially medical science, knows no borders and cannot advance effectively without the free international exchange of knowledge, ideas and skills among all its participants. For academics to suspend interactions with US colleagues or refuse to peer review and validate the work of US researchers risks weakening US science at the worst possible time, abandoning colleagues to face a political administration that already manifests a desire to muzzle federal scientists, ${ }^{4}$ escape accountability by the media and wage war on facts incompatible with its preferred narrative.
Breaking ties would also hurt the very people the protest is supposed to help. Hundreds of physicians, researchers and trainees from the countries proscribed by the executive order, and thousands more who may worry that their countries will be added to the list, are already living and working in the US. Understandably, they now fear to travel outside the US in case they may not be allowed to re-enter. ${ }^{5}$ Boycotting meetings in the US, or alternatively, moving US conferences to another country, would compromise the ability of these talented individuals to exchange knowledge with their colleagues, thereby further marginalizing many of those directly affected by the ban.

Although large conferences bolster local economies, any lost income from decreased international participation would hurt sponsoring academic and professional organizations and is unlikely to be substantial enough to trouble the Trump administration. A far more influential lever, however, is US public opinion. In this regard, the recent annual meeting in Boston of the American Association for the Advancement of Science is salient. Political discussion was rampant throughout many of its sessions and the conference culminated with hundreds of scientists joining together in a public rally, ${ }^{6}$ which received widespread media coverage - not least because the public is unaccustomed to seeing scientists engage in political action. Other conferences represent similar opportunities for participants to address publicly the impact of government policies on US academics and their international colleagues. As such, those inclined to oppose a Muslim ban and defend science might find their efforts better served by their attendance rather than their absence.

Although the travel ban targets individuals, its threat to the integrity and prosperity of scientific collaboration is of paramount concern. Physicians and scientists must not remain silent, but the best solution lies in more, rather than less, engagement with US colleagues. Survival of democracy depends on a primacy of truth and justice that transcends partisanship and ideology. The world's scholars must have faith that their US counterparts understand this and support them as best they can.

\section{References}

1. Svrluga S. 51 Nobel laureates, tens of thousands of academics sign protest of Trump immigration order. Washington Post 2017 Feb. 3. Available: www.washington post.com/news/grade-point/wp/2017/01/27/eleven-nobel-laureates-thousands -of-academics-sign-protest-of-trump-immigration-order/?utm_term=.96b326dabof (accessed 2017 Mar. 6). 
2. El-Enany N, Keenan S, Kundnani A, et al. In solidarity with people affected by the 'Muslim Ban': call for an academic boycott of international conferences held in the US. Available: https://docs.google.com/a/globe.com/forms/d/e/1FAIpQLSeNN _2HHREt1h-dm_CgWpFHw8NDPGLCkOwB4lLRFtKFJqI25w/viewform (accessed 2017 Mar. 6)

3. Oransky I, Marcus A. Scientists protest immigration ban with boycotts of journals, conferences. Boston: STAT; 2017 Feb. 1. Available: www.statnews.com /2017/02/01/scientists-protest-immigration-ban (accessed 2017 Mar. 6).

4. Palen W. When Canadian scientists were muzzled by their government. New York Times 2017 Feb. 14. Available: www.nytimes.com/2017/02/14/opinion/when -canadian-scientists-were-muzzled-by-their-government.html?_r=1 (accessed 2017 Mar. 6)
5. Reardon S. How the fallout from Trump's travel ban is reshaping science. Nature 2017 Mar. 2 [Epub ahead of print]. 10.1038/nature.2017.21579.

6. Sheridan K. Scientists gather to talk research, but political anxieties pervade. Boston: STAT; 2017 Feb. 20. Available: www.statnews.com/2017/02/20/aaas-politics -trump-scientists (accessed 2017 Mar. 6)

Competing interests: See www.cmaj.ca/site/misc/cmaj_staff.xhtml Affiliation: Deputy editor, CMAJ

Correspondence to: CMAJ editor,pubs@cmaj.ca 